\title{
Hepato-Renal Toxicity of Gongronema latifolium Extracts on Streptozocin Induced Diabetes in Rats
}

\author{
Brown Holy, Tamunoemine Davies, Thompson N. Imomoemi \\ Dept. of Medical Laboratory Science Rivers State University of Science and Technology, Npkolu, Port Harcourt, Nigeria
}

Email address:

hbinternational2002@yahoo.com (B. Holy),brown.holy01@ust.edu.ng (B. Holy)

To cite this article:

Brown Holy, Tamunoemine Davies, Thompson N. Imomoemi. Hepato-Renal Toxicity of Gongronema latifolium Extracts on Streptozocin Induced Diabetes in Rats. American Journal of Health Research. Vol. 4, No. 3, 2016, pp. 62-69. doi: 10.11648/j.ajhr.20160403.15

Received: April 22, 2016; Accepted: May 7, 2016; Published: May 14, 2016

\begin{abstract}
This study evaluated the effect of methanolic, ethanolic, aqueous and crude extracts of Gongronema latifolium leaves on some nephrotoxic and hepatotoxic parameters in streptozocin induced diabetic rats. Thirty albino rats divided into six experimental groups were used. Two groups served as control were fed normal saline and glibenclamide. Four groups were fed methanolic, ethanolic, crude and aqueous extracts of Gongronema latifolium leaves respectively. Treatment lasted four 14 days after which the rats were sacrificed and blood collected for biochemical evaluation. The results showed that treatment with all the various extracts of Gongronema latifolium leave did not cause any significant increase in the nephrotoxic and hepatotoxic parameters. Treatment with methanolic extract caused a significant decrease in the serum glutamate pyruvate transaminase activity $(\mathrm{P}<0.001)$. The histological analysis revealed a recovery from inflammatory phase of the cells of the kidney and liver from the toxic effect of the streptozocin.
\end{abstract}

Keywords: Hepatoxicity, Nephrotoxicity, Gongronema latifolium, Diabetes, Plant Extracts, Phytochemicals

\section{Introduction}

Currently available treatment options for diabetes are limited and have several adverse effects. Therefore, systemic and intensive search for new drugs to treat diabetes mellitus is ongoing. The research from plants source seems to be a great approach to develop novel drug prototypes due to the presence of secondary metabolites in them which are bioactive. These secondary metabolites are known as phytochemicals. They are the components in plants that give them their therapeutic medicinal effect. Several substances like glycosides, alkaloids, saponins, terpenoids, flavonoids and phenols are phytochemicals reported to have antidiabetic effects which can be a safe alternative for diabetes mellitus management.

Although several medicinal plants have gained importance in the management of diabetes, such as Allium sativum (garlic), Garcinia kola (bitter kola), Vernonia amygdalina (bitter leaf) and Viscum album (mistletoe) etc. There are more yet to be scientifically investigated [1].

Gongronema latifolium is widely used in West Africa for medicinal and nutritional purpose. An infusion of the aerial parts is taking to treat cough, intestinal worms, dysentery, dyspepsia and malaria. It is also taken as a tonic to treat loss of appetite. In Sierra Leone an infusion or decoction of the stems with lime juice is taken as a purge to treat colic and stomach-ache. In Senegal and Ghana the leaves are rubbed on the joints of small children to help them walk. A maceration of the leaves in alcohol is taken to treat viral hepatitis and as a general anti-microbial agent. [2]. Gongronema latifolium has been implicated in the reduction of blood glucose due to photochemical constituents present in them [3].

The administration of crude plants or extracts, can cause different biological effects in the body. Some of which could be harmful to different organs of the body. But mostly, the liver and the kidney. Sometimes, these toxic effects could be associated with only certain parts of the plant. For example, the leaves of Senna occidentalis was found to have hepatoprotective effects and is being used traditionally for the treatment of liver disorders [4] whereas, the ingestion of the seeds (beans) is thought to cause acute hepato-myoencephalopathy (HMP) in children. This risk of toxicity associated with the use of herbal products is one of the main reasons for the hesitance amongst healthcare practitioners towards promoting their integration into healthcare systems [5]. 
The aim of this study is to assess the nephrotoxic and hepatotoxic effect of methanolic, ethanolic, aqueous and crude extracts of Gongronema latifolium leaves on Streptozocin induced diabetic rats.

\section{Materials and Methods}

\subsection{Collection of Plant Materials}

The leaves of Gongronema latifolium was purchased from mile three (3) market in Port Harcourt, Rivers State and was authenticated by a botanist in the department of biology in Rivers State University of Science and Technology, Port Harcourt, Rivers State Nigeria.

\subsection{Preparation of Plant Extract}

The plants leaves were allowed to air dry for one (1) week. The dried leaves were ground into powder with an electric blender. The various extracts from methanol, ethanol and water was prepared using the hot continuous extraction method known as soxhlet extraction. While the crude extract was gotten using cold maceration method.

\subsubsection{Hot Continuous Extraction (Soxhlet)}

$50 \mathrm{~g}$ of the finely ground plant leaves was placed in a thimble, which was placed in the chamber of the soxhlet apparatus. While, $100 \mathrm{ml}$ of the extracting solvent was placed into the flask. The solvent was then heated to different temperatures depending on the boiling point of the extracting solvent, $100^{\circ} \mathrm{C}$ for aqueous, $78.3^{\circ} \mathrm{C}$ for ethanol and $64.7^{\circ} \mathrm{C}$ for methanol. The vapor from the solvent then moved up to the column and floods into the chamber containing the thimble with the dried plant leaves. The non-volatile compounds present in the leaves was then dissolved into the solvent which condensed back into the flask. This process was repeated until all the desired concentrated compounds in the plant in the chamber had been extracted. The extract and the solvent mixture was then put into a Rotary evaporator to be able to separate the extract from the solvent by evaporating the solvent from the mixture. After all the solvents had been removed the extract was finally placed on a water bath to remove all the moisture content. This was done at $45^{\circ} \mathrm{C}$ so as not to denature the plant constituents.

\subsubsection{Cold Maceration}

In preparing the crude plant cold maceration was used. $570 \mathrm{~g}$ of the finely ground dried plant leaves was immersed into the $1000 \mathrm{ml}$ of distilled water for 72 hour. It was then filtered using a Whatman filter paper. The water content of the extract was then evaporated by drying the mixture on a water bath at $45^{\circ} \mathrm{C}$.

\subsection{Collection of Animals}

The protocol employed met the guidelines of the Good Laboratory Practice (GLP) regulations of World Health Organization. Forty (45) albino rats of both sexes weighing between 190 and $240 \mathrm{~g}$ were purchased from an animal farm house in Enugu, Nigeria. The rats were allowed to acclimatize for 14 days in the laboratory in the animal farm house in the Department of Human Physiology, University of Port Harcourt, Rivers State. The rats were fed with normal rat feed and water ad libitum. 10 rats were used for a pilot study to ascertain the amount of streptozocin that could induce diabetes in the rat without being lethal. While the 30 rats left which were randomly grouped into 5 groups with five rats in the groups as shown in the table 1 below.

Table 1. Grouping of experimental rats.

\begin{tabular}{ll}
\hline s/no & Gongronema latifolium \\
\hline 1 & Methanol extract group \\
2 & Ethanol extract group \\
3 & Aqueous extract group \\
4 & Crude extract group \\
5 & Control 1 (glibenclamide) \\
6 & Control 2 (normal saline) \\
\hline
\end{tabular}

\subsection{Pilot Study}

A pilot study was first carried out using 10 albino rats which were grouped into five (5). The rats were given varying doses of streptozocin. Which include $30 \mathrm{mg} / \mathrm{kg}$ bodyweight, $45 \mathrm{mg} / \mathrm{kg}$ bodyweight, $50 \mathrm{mg} / \mathrm{kg}$ bodyweight, $55 \mathrm{mg} / \mathrm{kg}$ bodyweight and $60 \mathrm{mg} / \mathrm{kg}$ bodyweight. The rats fasting blood glucose was monitored daily for 1 week. The values obtained showed that the $45 \mathrm{mg} / \mathrm{kg}$ bodyweight dose for diabetic induction gave the required diabetic model for my experiment. Which is the model that is similar to type 2 diabetes. Where some pancreatic beta cell function is still left.

\subsubsection{Induction of the Rats}

Thirty five (35) albino rats were injected a $45 \mathrm{mg} / \mathrm{kg}$ bodyweight of streptozocin shown by the pilot study to induce diabetes without being lethal to them. The fasting blood glucose level of each rat was taken before injecting the rats with streptozocin to form a baseline glucose level of the rats which the mean was discovered to be $3.5 \mathrm{mmol} / 1$. The animals were fed freely with normal rat feed and water during the day but an overnight fast was maintained so that the fasting blood glucose level could be monitored every morning. A rise of the fasting blood glucose level was noted to occur on the $5^{\text {th }}$ day after induction of Diabetes. The mean value was $6.6 \mathrm{mmol} / \mathrm{l}$. 5 rats did not become diabetic at that day but as the average number of rats was already diabetic the administration of the extracts had to commence. So such rats were removed from the study.

\subsubsection{Administration of Plant Extracts}

Treatment of diabetic rats with the crude plant and various plant extracts commenced on the $6^{\text {th }}$ day, after streptozocin administration. $0.7 \mathrm{mls}$ of the extract was be administered orally for 2 weeks. This amount was calculated by using the median dose which is $200 \mathrm{mg} / \mathrm{kg}$.

\subsection{The Laboratory Analysis}

The blood samples for nephrotoxicity test and hepatotoxicity test was collected on 14th day of 
administration of the extracts. The samples were collected from the animals sacrificed under $70 \%$ chloroform anesthesia into a plain specimen bottle. The samples were allowed to clot, then centrifuged at 3000 revolutions per minute for 3 minutes. The sera obtained were stored in a freezer until required for use in analysis. The serum collected was used for biochemical analysis of alkaline phosphatase (ALP), serum glutamate oxaloacetate transaminase (SGOT), serum glutamate pyruvate transaminase (SGPT) using the Elitech reagent kit following the continuous monitoring assay methods of kinetics. While the urea and creatinine were determined colorimetrically, also using Elitech reagent kit following the method described by Teitz. The samples were assayed using the Selectra PROS chemistry auto-analyzer with quality controls, following the required standard operating procedures (SOP's).

\subsection{Histological Studies}

On the $14^{\text {th }}$ day of administration of the extracts to the streptozocin induced diabetic rats one from each group was randomly chosen that was dissected to obtain the kidney and liver. The samples collected were placed in $10 \%$ formal saline for histological examination at the University of Port Harcourt Teaching Hospital Histology Laboratory.

\subsection{Statistical Studies}

The results were analysed using SPSS version 20. Oneway analysis of variance (ANOVA) was used to compare means followed by Post Hoc LSD multiple comparison test where p-values were significant. P-value $<0.05$ was considered statistically significant.

\section{Results}

Table 2. Phytochemical Analysis of various extracts of Gongronema latifolium leaves.

\begin{tabular}{|c|c|c|c|c|}
\hline & Methanol extract & Ethanol extract & Aqueous extract & Crude extract \\
\hline \multicolumn{5}{|l|}{ Alkaloids test: } \\
\hline a) Mayers reagent test & $+\mathrm{ve}$ & ++ ve & $+\mathrm{ve}$ & $+\mathrm{ve}$ \\
\hline b) Hagers reagent test & $+\mathrm{ve}$ & ++ ve & $+\mathrm{ve}$ & $+\mathrm{ve}$ \\
\hline c) Drangendoff's reagent test & $+\mathrm{ve}$ & ++ ve & $+\mathrm{ve}$ & $+\mathrm{ve}$ \\
\hline \multicolumn{5}{|l|}{ Tannins test: } \\
\hline a) Ferric chloride test & -ve & $++\mathrm{ve}$ & $+\mathrm{ve}$ & + ve \\
\hline b) Bromine water test & $-\mathrm{ve}$ & ++ ve & $+\mathrm{ve}$ & $+\mathrm{ve}$ \\
\hline \multicolumn{5}{|l|}{ Phlobatamins test: } \\
\hline a) Hydrochloric test & -ve & -ve & -ve & -ve \\
\hline b) $40 \%$ formaldehyde test & -ve & -ve & -ve & -ve \\
\hline \multicolumn{5}{|l|}{ Anthraquinnones: } \\
\hline a) Free anthraquinnones & -ve & -ve & -ve & -ve \\
\hline b) Combine anthraquinnones & -ve & -ve & -ve & -ve \\
\hline \multicolumn{5}{|l|}{ Flavonoids test: } \\
\hline a) Test for shinoda reduction & + ve & ++ ve & + ve & -ve \\
\hline \multicolumn{5}{|l|}{ Carbohydrate test } \\
\hline a) Molisch test & $+\mathrm{ve}$ & ++ ve & $+\mathrm{ve}$ & -ve \\
\hline b) Fehling test for sugar reduction & $+\mathrm{ve}$ & ++ ve & $+\mathrm{ve}$ & -ve \\
\hline \multicolumn{5}{|l|}{ Saponin Glycosides test: } \\
\hline a) Frothing test & + ve & $++\mathrm{ve}$ & $+\mathrm{ve}$ & -ve \\
\hline b) Emulsion test & $+\mathrm{ve}$ & $+\mathrm{ve}$ & $+\mathrm{ve}$ & -ve \\
\hline \multicolumn{5}{|l|}{ Cardiac glycoside test: } \\
\hline a) Salwoski test & -ve & ++ ve & $+\mathrm{ve}$ & -ve \\
\hline b) Kedde test & $-\mathrm{ve}$ & $++\mathrm{ve}$ & $+\mathrm{ve}$ & -ve \\
\hline
\end{tabular}

Note: The results are expressed based on if present + , present in excess ++ and not detected ND

Table 2 shows the results of the phytochemical analysis of methanol extract, ethanol extract, aqueous extract and crude extract of Gongronema latifolium leaves.

Table 3. Evaluation of blood Urea and Creatinine levels in diabetes rats treated with various media of Gongronema latifolium leave extracts.

\begin{tabular}{lll}
\hline GROUPS & UREA (mg/dl \pm SEM) & CREATININE (mg/dl \pm SEM) \\
\hline Methanol & $39.40 \pm 3.33$ & $0.43 \pm 0.05$ \\
Ethanol & $42.20 \pm 4.41$ & $0.47 \pm 0.03$ \\
Aqueous & $39.40 \pm 3.59$ & $0.55 \pm 0.03$ \\
Crude & $42.60 \pm 2.77$ & $0.49 \pm 0.04$ \\
Control 1 (gliben) & $35.20 \pm 3.20$ & $0.44 \pm 0.02$ \\
Control 2 (saline) & $30.0 \pm 2.07$ & $0.45 \pm 0.03$ \\
\hline
\end{tabular}

Values are presented as mean \pm SEM. $n=5, *$ mean values are statistically significant compared to the control (saline). 
Table 3 shows the results of the urea and creatinine concentrations of streptozocin induced diabetic rats fed with methanol, ethanol, aqueous and crude extract of Gongronema latifolium leaves after fourteen (14) days. The result showing the effect of rats fed the various extracts of Gongronema latifolium leave on the urea and creatinine concentration were statistically nonsignificant compared to rats fed normal saline $(\mathrm{P}>0.05)$.

Table 4. Evaluation of some liver enzyme levels in diabetes rats treated with various solvent media of Gongronema latifolium leave extracts.

\begin{tabular}{llll}
\hline GROUPS & ALP $($ U/L \pm SEM) & GOT $($ U/L \pm SEM) & GPT (U/L \pm SEM) \\
\hline methanol & $416.80 \pm 36.50$ & $275.0 \pm 55.83$ & $4.20 \pm 2.01^{*}$ \\
Ethanol & $318.20 \pm 49.34$ & $235.20 \pm 79.24$ & $29.40 \pm 13.24$ \\
Aqueous & $569.60 \pm 161.17$ & $230.40 \pm 45.49$ & $91.40 \pm 13.27$ \\
Crude & $380.40 \pm 18.50$ & $96.40 \pm 37.08$ & $31.0 \pm 31.0$ \\
Control 1 (gliben) & $379.0 \pm 31.13$ & $254.80 \pm 58.59$ & $25.20 \pm 21.81$ \\
Control 2 (saline) & $590.40 \pm 66.62$ & $224.20 \pm 18.19$ & $97.80 \pm 10.41$ \\
\hline
\end{tabular}

Values are presented as mean \pm SEM. $n=5, *$ mean values are statistically significant compared to the control (saline)

Table 4 shows the results of the serum alkaline phosphatase, serum glutamate oxaloacetate and serum pyruvate oxaloacetate concentrations of streptozocin induced diabetic rats fed with methanol, ethanol, aqueous and crude extract of Gongronema latifolium leaves after fourteen (14) days. The results showing the effect of Gongronema latifolium extract on the hepatic indices of the rats were statistically not significantly different $(\mathrm{P}>0.05)$ compared to controls, for serum alkaline phosphatase and for serum glutamate oxaloacetate, while the result showing the effect of methanolic extract of Gongronema latifolium leave on serum pyruvate transaminase was significantly reduced compared to control $(\mathrm{P}<0.001)$.

Pictures showing the histological findings of the liver and kidney harvested from one rat from each of the various groups are shown below.

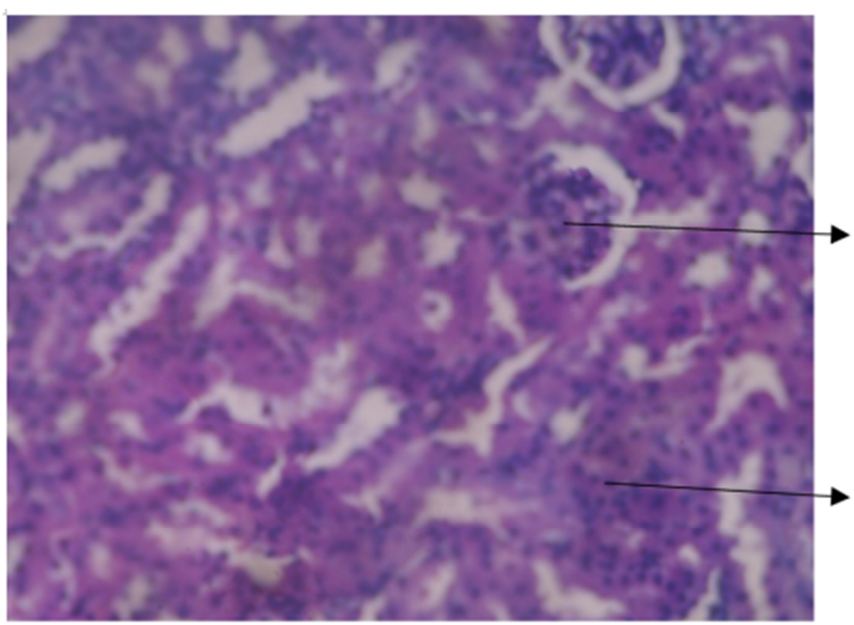

Encroached space of Disse with cellular debris and fluid (evidence of inflammatory response)

Fig. 1. Photo micrographic slide of liver organ of group (control saline) $H \& E X 400$.

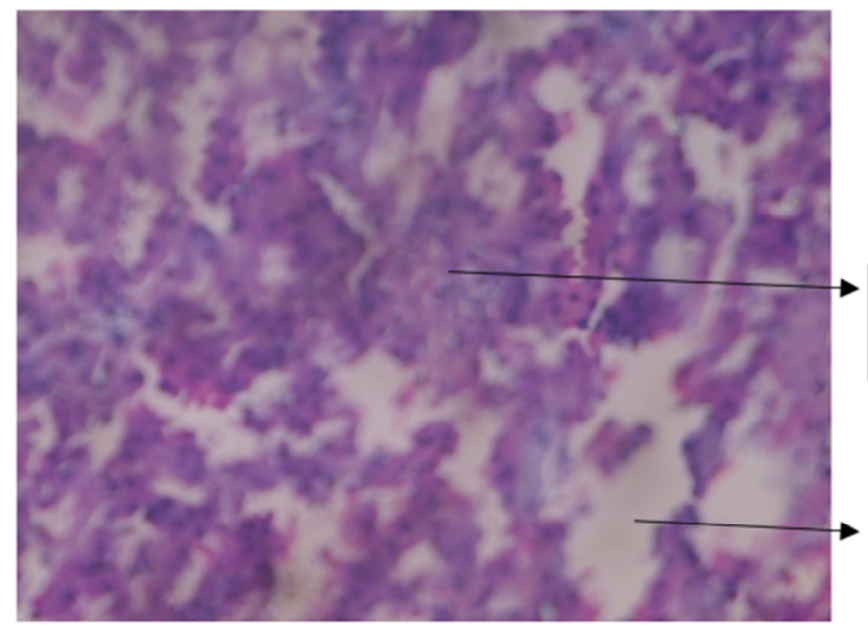

Filled portal tract with cells such as erythroid, immune cells and kupffer cells)

Fig. 2. Photo micrographic slide of liver organ of group 2 (positive control drug) $H \& E X 400$ 


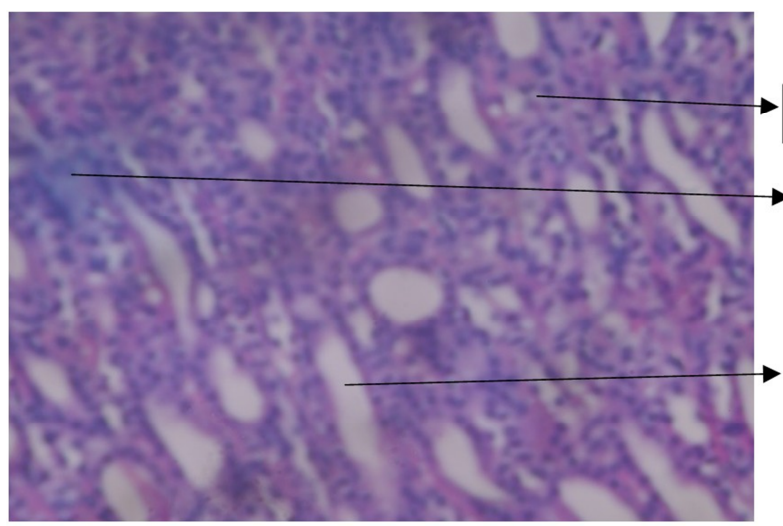

Healthy hepatic matrix evolving

Inflamed area of the cell recovering from the phase of inflammation

Space of Disse becoming devoid of cellular debris

Fig. 3. Photo micrographic slide of liver organ of group 3 using methanolic extract of Gangronema latifolium (200mg/kg). H \& EX400.

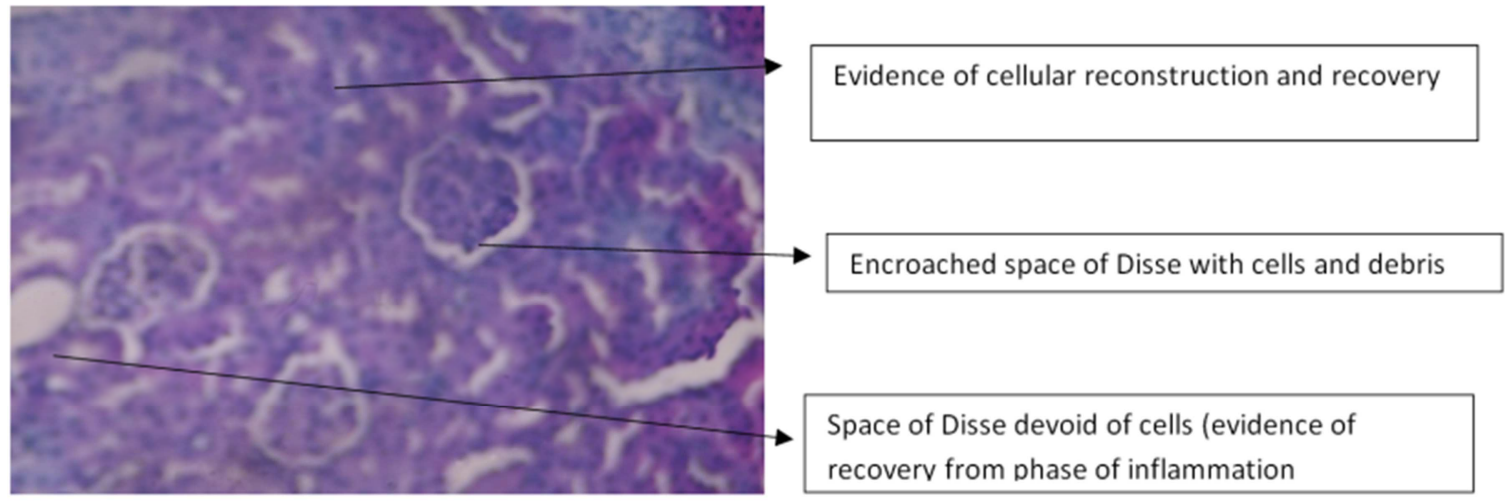

Fig. 4. Photo micrographic slide of liver organ of group 4 using ethanolic extract of Gangronema latifolium (200mg/kg). H \& E X400.

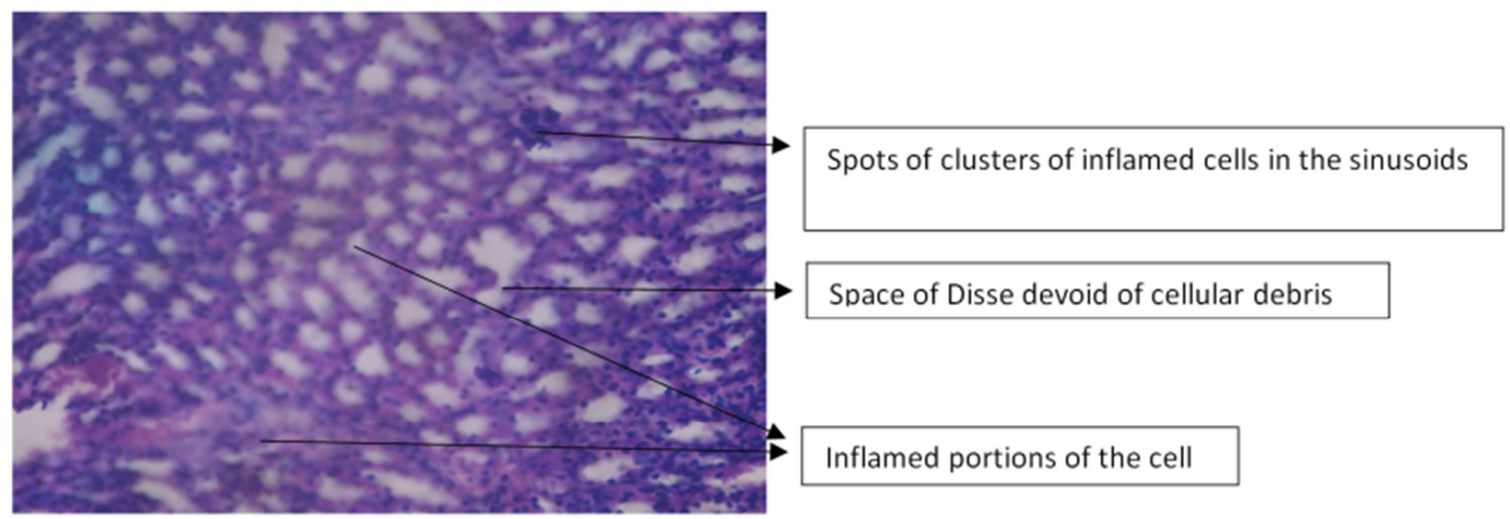

Fig. 5. Photo micrographic slide of liver organ of group 5 using aqueous extract of Gangronema latifolium (200mg/kg). H \& E X400.

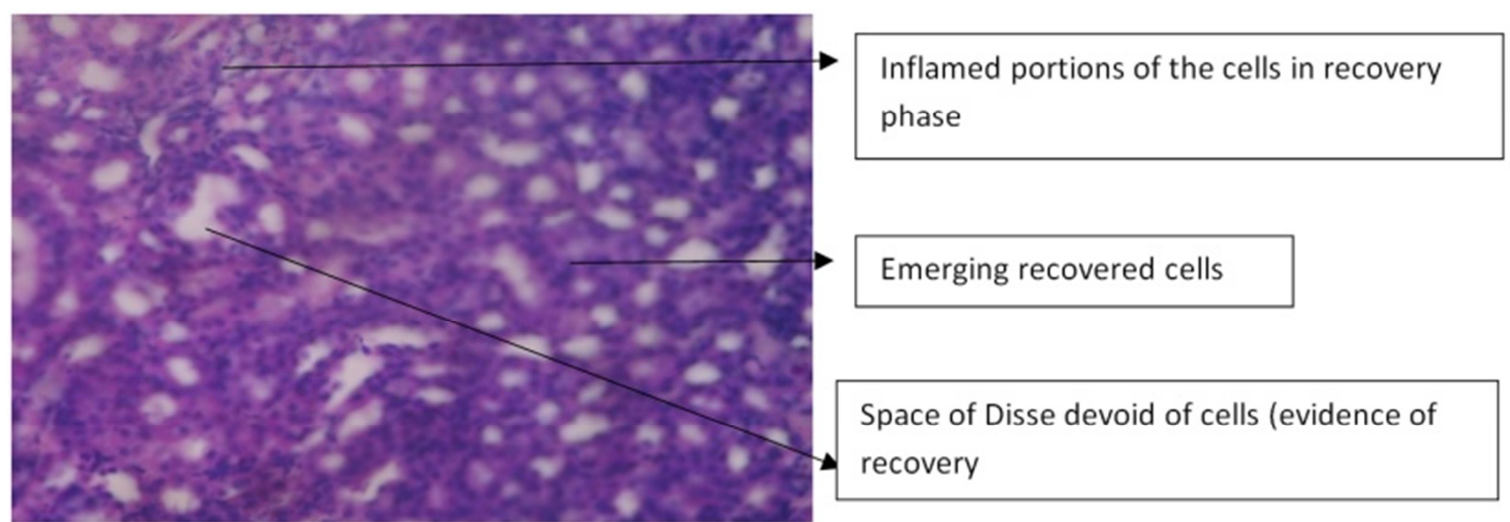

Fig. 6. Photo micrographic slide of liver organ of group 6 using crude extract of Gangronema latifolium (200mg/kg). H \& E X400. 


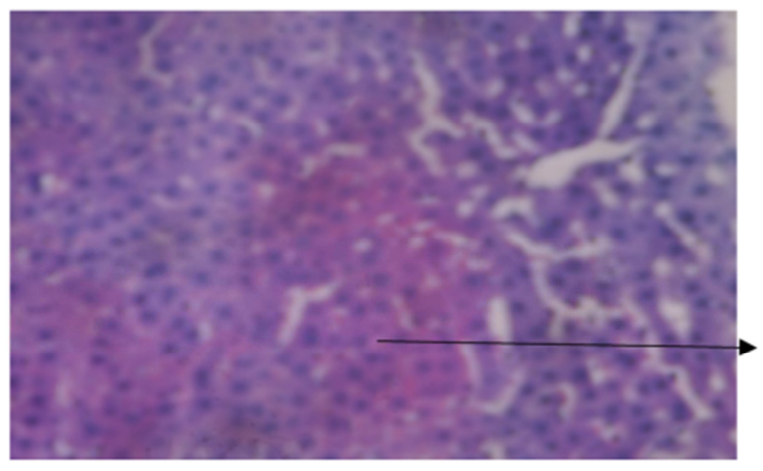

Inflamed centroacinar cells observed to be reddish

Fig. 7. Photo micrographic slide of kidney organ of group (control saline).

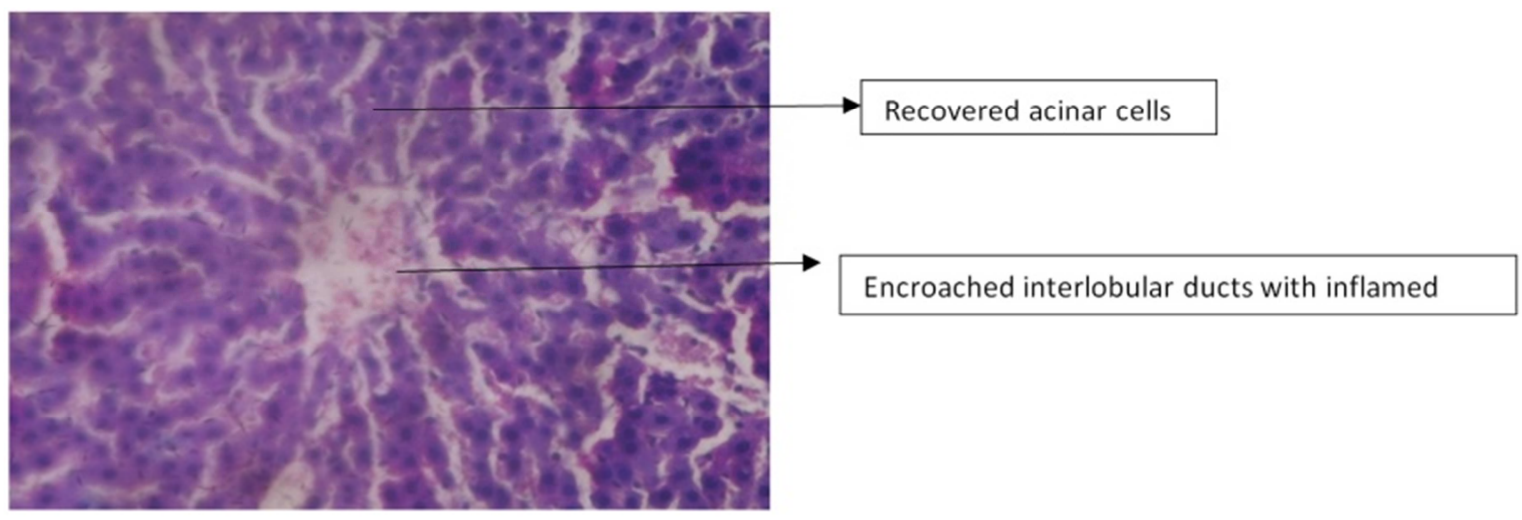

Fig. 8. Photo micrographic slide of kidney organ of group 2 (positive control drug).

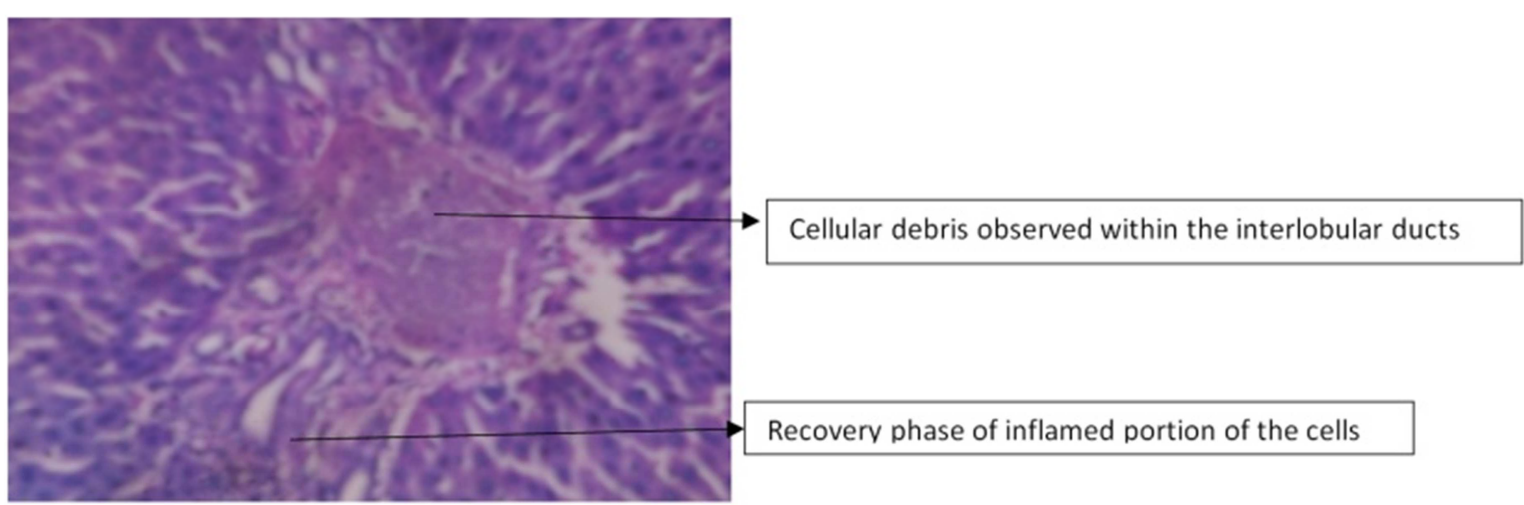

Fig. 9. Photo micrographic slide of kidney organ of group 3 using methanolic extract of Gangronema latifolium (200mg/kg).

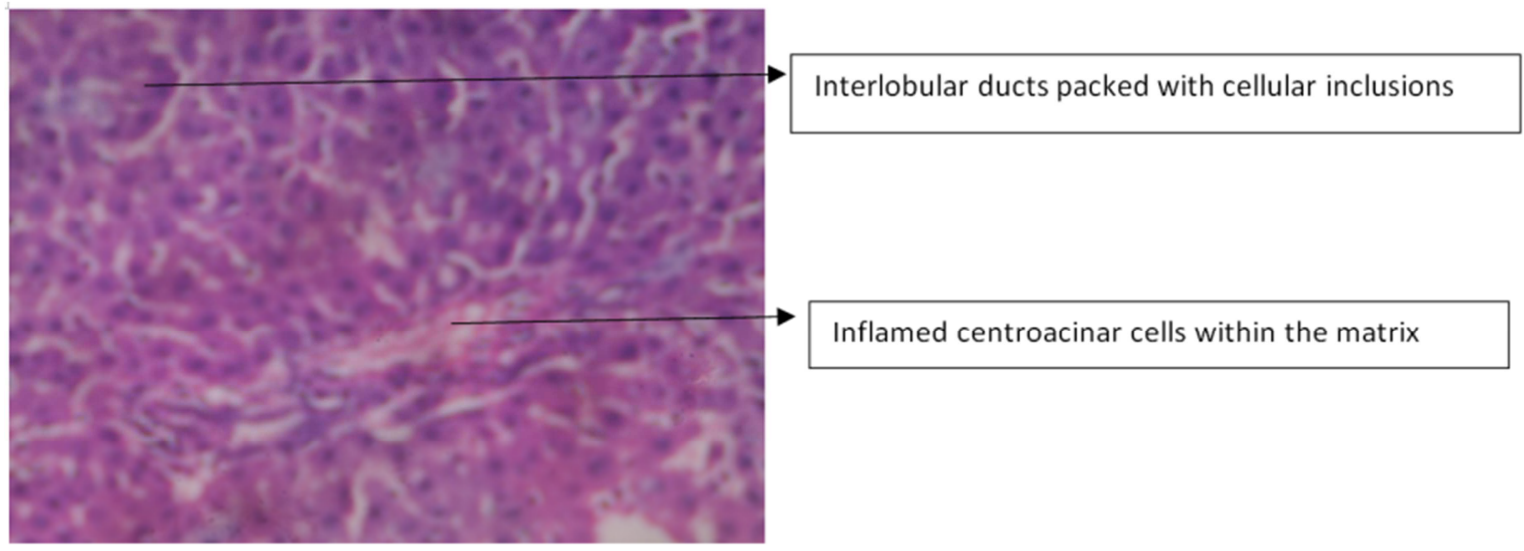

Fig. 10. Photo micrographic slide of kidney organ of group 3 using methanolic extract of pawpaw (200mg/kg). 


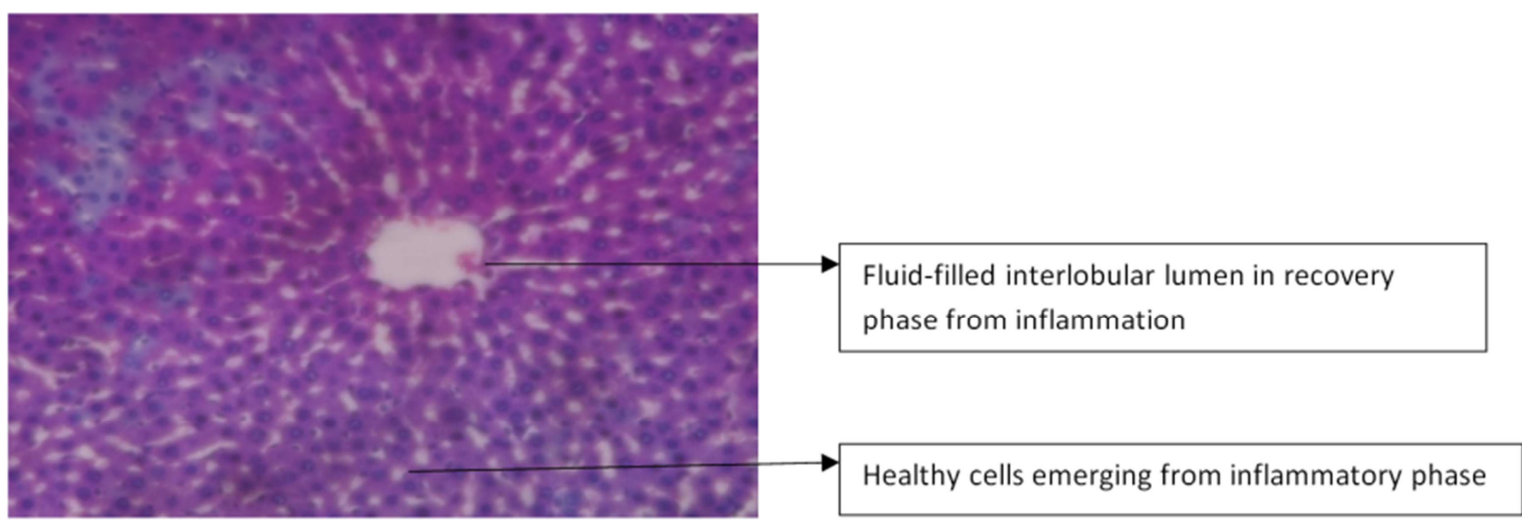

Fig. 11. Photo micrographic slide of kidney organ of group 4 using ethanolic extract of Gangronema latifolium (200mg/kg).

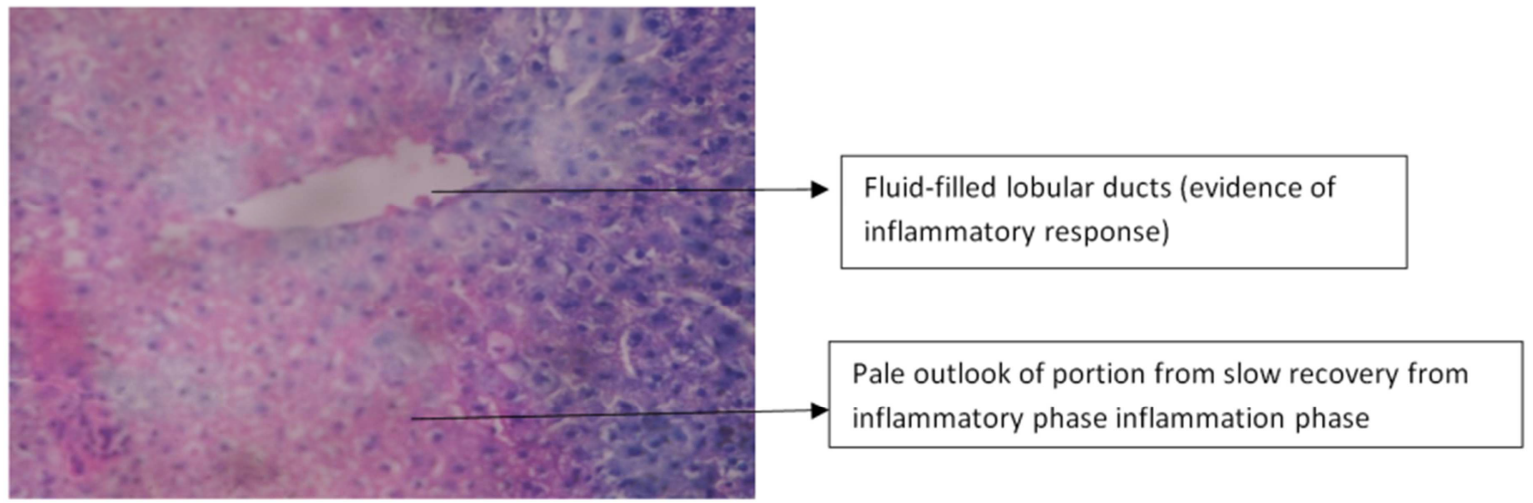

Fig. 12. Photo micrographic slide of kidney organ of group 4 using ethanolic extract of pawpaw (200mg/kg).

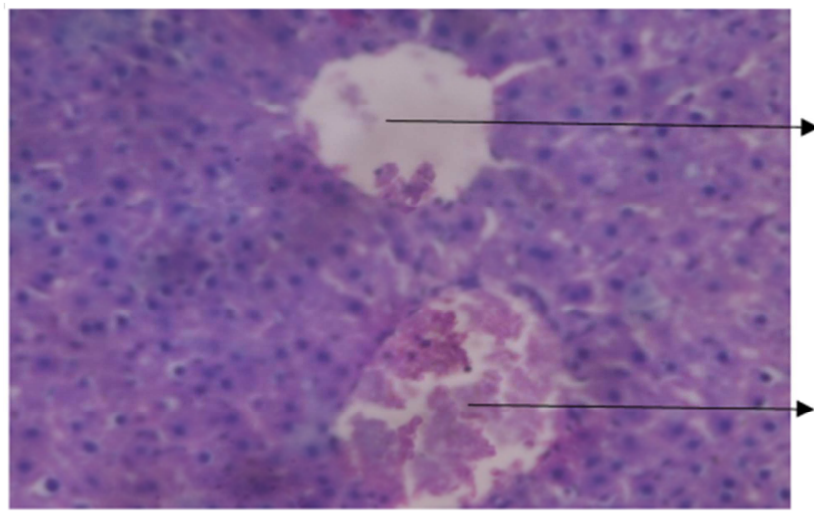

Fluid-filled interlobular duct devoid of cellular debris \& immune cells (recovery phase)

Encroached interlobular duct with cellular debris (inflammatory phase)

Fig. 13. Photo micrographic slide of kidney organ of group 5 using aqueous extract of Gangronema latifolium (200mg/kg).

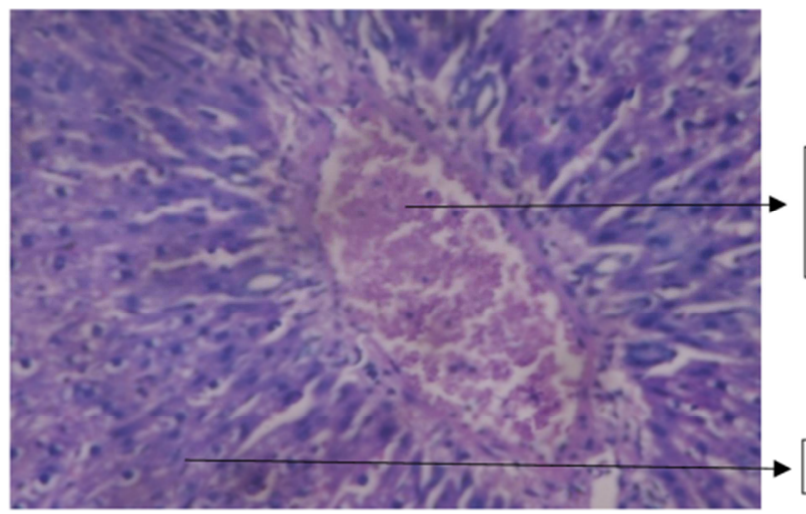

Large inflamed, infiltrated interlobular cell with cellular debris (inflammatory response)

Inflamed portions of the cell

Fig. 14. Photo micrographic slide of kidney organ of group 6 using crude extract of Gangronema latifolium (200mg/kg). 


\section{Discussion}

Phytochemicals are the therapeutic bioactive constituents in plants. The pharmaceutical industry has been able to harness some of the benefits of phytochemicals. Approximately $25 \%$ of all prescribed medicines today are substances derived from plants. Regrettably, however, not many of them have been exploited for clinical use. These metabolites are able to produce definite health benefits in the human body system. Anti-inflammatory activities of plants have been attributed to bioactive components, such as alkaloids, saponins, tannin, flavonoids, steroids, anthraquinnones [6]. The phytochemical results of this studies revealed that Gongronema latifolium leave contains phytochemicals with health benefits.

The results showed that the various extracts did not cause any statistically significant increase in the nephrotic and hepatic parameters of all the extracts compared with the control fed normal saline. There was instead a statistically significant decrease in the serum pyruvate oxaloacetate concentration (GPT) in rats fed with the methanolic extract. From this study Gongronema latifolium leave extract is found not to have nephrotoxic and hepatotoxic effect. This confirms the previous studies carried out by [7] which reported that Gongronema latifolium may be non haematotoxic, nonhepatotoxic and non-nephrotoxic at the doses studied.

The slides showed recovery of the kidney and liver cells from the toxic effect of the streptozocin. This shows that the various extracts have hepatoprotective and nephroprotective properties. This confirms the review reported by [8] where the fruit of Carica papaya has also been discovered to be used as a popular hepatoprotective agent. Toxicity of the liver induced by carbon tetrachloride in albino rats was found to be relieved by the ethanolic extract of Gongronema latifolium [9]. Carbon tetrachloride induction in the rats resulted in hepatic injuries hence the marker of liver damage AST and ALT was reported to be significantly high in carbon tetrachloride induced rats, however ALP was not significantly increased. It is well documented from histological studies on the liver that necrosis in the centrilobular zone is a major cause of carbon tetrachloride induced acute liver injury [10]. Treatment with the ethanol extract of Gongronema latifolium was shown to reduce the AST and ALT concentration significantly. Reduced levels of ALT and AST in rats treated with the extract could be attributed to the ability of the extract to prevent the metabolism of carbon tetrachloride into more toxic metabolite and minimized the production of free radicals and also boost the activities of the scavengers of free radicals [11] thus minimizing hepatocellular injury produced.

\section{Conclusion}

The findings from this study shows that Gongronema latifolium leave contains phytochemicals with health benefits and its extracts at the dose used in this study did not cause hepato-renal toxicity, instead it aided in recovery from toxic damage of the cells of the liver and kidney that were caused by the induced diabetes. Extracts from various extraction methods used in this study did not cause any statistically significant change in the nephrotic and hepatic parameters of all test group compared with the control. It is needful to explore and harness the health benefits in this plant

\section{References}

[1] Punitha R., Shirwaika A, Shirwaikar A (2005). Anti-diabetic activity of benzyl tetraisoquinoline alkaloid, berberine, in streptozocin-nicotinamide induced type 2 diabetic rats. Diabetologian Croat., 34 (4): 117-121.

[2] Eleyinmi A. F. Sporns P. and Bressler D. C., 2008. Nutritional composition of Gongronema latifolium and Vernonia amygdalina. Nutrition \& Food Science, 38 (2), 99-109.

[3] Saidu A. N and Okorocha S. C (2013). Phytochemical Screening and Hypoglycemic Effect of Methanolic Extract of Gongronema latifolium leaf in alloxan induced diabetic rats. Journal of Emerging Trends in Engineering and Sciences, 4 (6), 855-858.

[4] Jafri M. A., Subhani M. J., K. Javed K. and Singh S. (1999). Hepatoprotective activity of leaves of Cassia occidentalis against paracetamol and ethyl alcohol intoxication in rats. Journal of Ethnopharmacology, 66: 355-61.

[5] Vashishtha V. M., John T. J. and Kumar A. (2009). Clinical and pathological features of acute toxicity due to Cassia occidentalisin vertebrates. Indian Journal of Medical Research, 130: 23-30.

[6] Balogun M. E., Besong E. E., Obimma J. N., Mbamalu O. S. and Djobissie S. F. A. (2016). Latifolium: A Phytochemical, Nutritional and Pharmacological Review, Journal of Physiology and Pharmacological Advances, 6 (1): 811-824.

[7] Effiong G. S., Udoh I. E., Mbagwu H. O. C., Ekpe I. P., Asuquo E. N., Atangwho I. J. and Ebong P. E (2012). Acute and chronic toxicity studies of the ethanol leaf extract of Gongronema latifolium. International Research Journal of Biochemistry and Bioinformatics, 2 (7), 155-161.

[8] Augustine O., Nonye C. N. and Nicholas T. K. D. (2012). Phytochemical characterization and comparative efficacies of crude extracts of carica papaya. International Journal of Drug Research and Technology, 2 (5), 399- 406.

[9] Etim O. E., Akpan, E. J. and Usoh, I. F., 2008. Hepatotoxicity of carbon tetrachloride: protective effect of Gongronema latifolium. Pakistan Journal of Pharmaceutical Sciences 21 (3): 269-274.

[10] Shi J., Asiaki K., Ikawa Y. and Wake K. (2003). Evidence of hepatocyte apoptosis in rat liver after the administration of carbontetrachloride. Journal of Medical Research, 4: 1-8.

[11] Chung H. S., Chong, L. C., Lee S. K., Shamon L. A., Breemen R. B. V., Mehta R. G., Farnsworth N. R., Pezzuto J. N. and Kinghorn A. D. (1999). Flavonoids constituents of chlorinzan diffused with potential cancer chemopreventive activity. Journal of Agriculture Food Chemistry, 47: 35-4. 